Donald F. Reindl

Indiana University, Bloomington

\title{
Hierarchical Ambiguities in Copula Coordinate Structures in Slovene and Other Slavic Languages
}

\begin{abstract}
Raziskovalci od Aristotela in Dionizija Traškega do Bloomfielda in Chomskega so razpravljali o lastnostih prirednosti, npr. o derivaciji in članstvu v prirednih strukturah. Vezalno priredje lahko izraža pomen 'in' z vezanjem, ki ga je možno nadalje deliti na štiri razrede. Vsi se uporabljajo $\mathrm{v}$ slovanskih jezikih. $\mathrm{V}$ teh strukturah je mogoče prepoznati tudi nekatere vrste dvoumnosti. Proti pričakovanju lahko poleg klasičnih jezikov (npr. stare perziǰ̌čine) tudi nekateri slovanski jeziki v teh strukturah besedno razlikujejo članstvo na višji in nižji ravni. Slovenščina v ta namen uporablja veznike ter, in, pa. Drugi mehanizem, s predlogom $z(s)$, npr. midva s Petrom, lahko izraža še nižjo raven prirednosti.

The nature of coordination, including derivation and constituency in coordinate structures, was debated by earlier writers, such as Aristotle and Dionysius Thrax, up to the present day by linguists such as Bloomfield and Chomsky. Copulative coordination expressing the meaning 'and' is achieved in four different ways, each of which are realized in the Slavic languages. It is also possible to find some kinds of ambiguity in these structures. Contrary to expectations, in addition to classical languages (e.g., Old Persian), some Slavic languages distinguish constituency on both higher and lower levels in these structures. Slovene uses the conjunctions ter, in, $p a$ for these purposes. Another mechanism, with the preposition $z$ (s) (e.g., midva s Petrom), expresses a lower level of coordination.
\end{abstract}

\section{Introduction}

Coordination has received attention as a topic of linguistic research for a number of reasons. ${ }^{1}$ One of the most frequently cited is that it appears to be a linguistic universal (Dik 1968: 1, Sag et al. 1985: 133, Oirsouw 1987: 1). Another reason is that some coordinate structures are a source for the "immanent productivity of natural languages" (Dik 1968: 1); coordination is one means by which we may form an infinite set of new sentences. Finally, and most intriguing, is the fact that the structural analysis of coordination has remained controversial (Oirsouw 1987: 1). The debate over whether coordination has a typical X-bar binary structure is very much alive today (cf. Borsley 1994).

\subsection{Early Work}

Interest in coordinate structures is not a recent phenomenon. Many of the issues being debated today were considered by earlier grammarians, or at least have their roots in the analyses of these thinkers.

\footnotetext{
${ }^{1}$ I would like to thank those native speakers who provided and corroborated my data: Bożena Shallcross (Polish), Dmitri Savintsev (Russian), Bogdan Rakić (Serbo-Croatian), and Peter Mikek and Jera Rojko (Slovene), as well as Steven Franks for his comments on an earlier version of this paper.
} 
For example, in De Sophisticis Elenchis Aristotle observes that "five is two and three" does not imply that "five is two and five is three" (cited in Dik 1968: 227). Over two thousand years later, the inadequacy of deriving all coordination from grammatical sentence-coordination à la Chomsky's Syntactic Structures has been criticized on the basis of just such sentences (cf. Oirsouw 1987: $5 \mathrm{ff}$.).

Similarly, Dionysius Thrax distinguished within his category of $\sigma u ́ v \delta \varepsilon \sigma \mu o t$

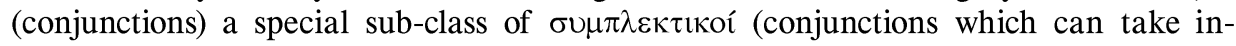
finite arguments). As Simon C. Dik (1986: 26) observes, this distinction has implications for transformational grammar; since not all coordinations can have unlimited constituents, coordination per se is not necessarily a source of infinite generation of new sentences.

Even in our own century, Bloomfield recognized another important (and much discussed) property of coordinate structures: structural ambiguity. In his Linguistic Aspects of Science (1939), he notes that "an apple and a pear or a peach" may denote exactly two pieces of fruit, or a choice between one piece or two (cited in Dik 1967: 227). That is,

(1)

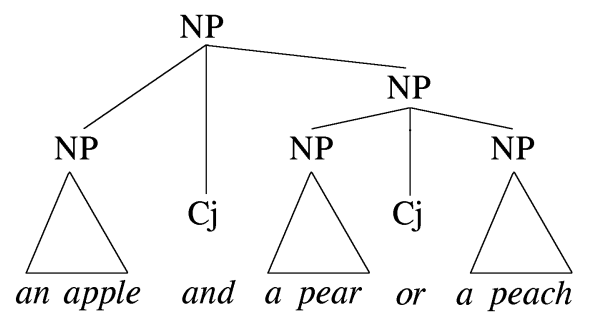

or:

(2)

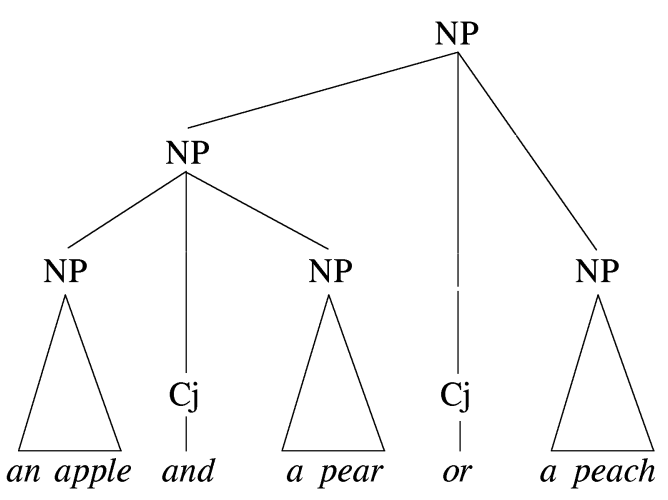

It is this last aspect of coordinate structures, their ambiguity, which will be addressed in this paper. 


\section{Coordination: Types and Mechanisms}

Various types of coordination are recognized: copulative (A and $B$ ), disjunctive (A or B), resultative (A since B), adversative (A but B), concessive (A though B), etc. ${ }^{2}$ Only the first of these will be addressed in this paper.

Traditionally, three types of mechanisms are cited for the expression of copulative coordination: parataxis, composition and conjunction.

\subsection{Parataxis (Asyndeton)}

Parataxis ${ }^{3}$ consists of the simple juxtaposition of coordinated elements (A B). Parataxis is perhaps the most ancient of the coordinate mechanisms. Its use is common in many languages, including Slavic; the following are from Russian and Upper Sorbian:

(3) Včera ja kupil knigi, karandaši.

'Yesterday I bought books, pencils.'

(4) We wsy, w polu, w holi, w haju knježi starosć žiwjenja. 'Apprehension about life reigns in the village, in the field, on the heath, in the woods.' (Rězak 1920: 984)

In other Slavic languages in which parataxis is not widespread (e.g., Kashubian), it is nonetheless occasionally employed:

(5) $V$ sobæta vječór wæn přińdze do mje, sadnje do stotu, njic nje řeče. 'On Saturday evening he comes to me, sits at the table, says nothing.' (Lorentz 1919: 87)

Frequently, paratactic coordination is used for lists. A characteristic example from Ukrainian is:

(6) My majemo dva dyvany, p'jat' krisel, šist' ližok, odyn kuxonnyj stil i šist' stil'civ, odin holodyl'nyk.

'We have two sofas, five armchairs, six beds, one kitchen table and six chairs, one refrigerator.' (Slavutych 1959: 130)

and, in Slovene:

(7) Iz srca namreč prihajajo hudobne misli, uboji, prešuštva, nečistovanja, tatvine, kriva pričevanja, bogokletstva.

'From the heart proceed namely evil thoughts, murders, adulteries, fornications, thefts, false witnesses, blasphemies.' (Mt 15: 19)

\subsection{Composition}

Composition, which consists of the fusion of two coordinated elements (AB), is highly developed in some languages, especially ancient ones; e.g., Sanskrit: satyānrté 'truth and falsehood', krtäkrtám 'done and undone', or even devagandharvamā-

\footnotetext{
${ }^{2}$ It is notable that many languages have refinements of coordinated types which are often not expressed in English. German aber/sondern 'but', Hungarian vagy ... vagy/akár ... akár 'either ... or', Russian i/a 'and' are well-known examples.

${ }^{3}$ Properly speaking, parataxis is coordination without a conjunction, while asyndeton is coordination which omits an expected conjunction. Although the latter has been used extensively in the literature on coordination, I shall use the former, as it is a somewhat broader term.
} 
nușoragarakșasās 'gods, heavenly musicians, men, serpents and demons' (Whitney 1931: 481). ${ }^{4}$ With the possible exception of compound numbers (i.e., twenty-one = one and twenty), modern Indo-European languages do not frequently use this device; German Butterbrot 'bread and butter' is one such example. These constructions are rarely, if ever, encountered in Slavic languages.

\subsection{Conjunction}

Conjunction, which links conjuncts with a $\mathrm{Cj}(\mathrm{A} \mathrm{Cj} \mathrm{B})$, is the most common type of coordination in Slavic, as it is in modern Indo-European languages in general. Analysis of this type of construction will form the major part of this paper.

Robert R. van Oirsouw (1983: 142-44) distinguishes four types of conjunction: ordered, identity, concomitant and coincidental. As will be seen, it is necessary to make a distinction between these types of conjunction in order to attain a coherent picture of coordinate structure in Slavic.

\subsubsection{Ordered Conjunction}

Ordered conjunction necessarily occurs between VPs (or Ss containing VPs), since it implies a non-symmetrical temporal ordering of the conjuncts. An example similar to that given by Oirsouw is the following, from Russian:

(8) ...vijali telo ego $i$ pogrebli ego.

'they took his body and buried it.' (Mt 14: 12)

Although this example may be analyzed as a coordination of 'They took his body' and 'They buried his body', the order obviously may not be reversed, as it could be in:

(9) On el mjaso $i$ pil pivo.

'He ate meat and drank beer.'

even though Russian does not mark the two constructions differently.

However, in Slovene a different conjunction is frequently used-namely, ter. ${ }^{5}$ The Slovene version of (8) reads:

(10) ... so ... vzeli truplo ter ga pokopali ...

'... they took the body and buried it ...'

A similar example of sequentiality is seen in:

(11) ... zgrabila me je za lase ter me treščila $v$ prah.

'... she grabbed me by the hair and flung me in the dust.' (Cankar 1920: 32)

Bulgarian can use the cognate $\mathrm{Cj}$ ta for the same purpose:

(12) Türkulna se prez glava, ta čak $v$ dola. 'He turned a somersault and rolled all the way to the hollow.' (Atanassova et al. 1990: 909).

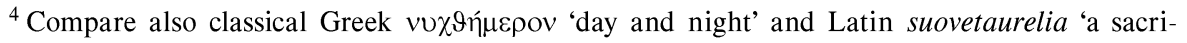
fice of a pig, sheep and bull' (MacDonell 1927: 169).

5 The Russian cognate of this word, to, has become a consequential $\mathrm{Cj}$ : Raz tak, to ja ne poj$d u$. 'If so, then I shall not go.'
} 
as can Eastern Ruthenian:

(13) Ydit' do vašoji komnaty ta učit'sja.

'Go upstairs to your room and study.' (Magocsi 1979: 55) tian:

Although te, the Serbo-Croatian cognate of ter, is seen in literary Serbo-Croa-

(14) Dodi odmah te namesti krevet.

'Come and make your bed immediately.'

it is perceived as old-fashioned and its use is seen as stilted.

It should be noted that, though quite acceptable, the Slovene ter in examples (10) and (11) is by no means obligatory, and is often felt to be synonymous with in. In fact, Mt. 14: 12, cited in (10), continues:

(15) ... potem so šli in to sporočili Jezusu.

'... then they went and told it to Jesus.'

where surely there is an equal degree of sequentiality.

\subsubsection{Identity Conjunction}

Identity conjunction establishes an identity between two conjuncts, presumably derived from 'A is C and B is C'; for example:

(16) Moja sestra in tvoj brat sta bila v Ljubljani.

'My sister and your brother were in Ljubljana.'

which may be analyzed as a coordination of

(17) Moja sestra je bila $v$ Ljubljani in tvoj brat je bil $v$ Ljubljani. 'My sister was in Ljubljana and your brother was in Ljubljana.'

Again, Slovene does not mark this conjunction differently from, for example:

(18) Dva in tri je pet.

'Two and three are five.'

which, as we have seen in 1.1 , is not a case of identity conjunction.

\subsubsection{Concomitant Conjunction}

Concomitant conjunction links two or more related sentences, without there necessarily being any overt identity. Because of this, these sentences are not subject to gapping or reduction. For example, in Russian:

(19) Solnce svetit i nebo jasnoe.

'The sun is shining and the sky is clear.'

As has been noted elsewhere, they must nonetheless have some shared relevance to the discourse. Example (19) is cohesive because of the consistent theme of weather, but it would be difficult to imagine a situation in which one could say:

(20) ?Moskva bol'šoj gorod i moja sestra s"ela dve ryby.

'Moscow is a big city and my sister ate two fish.'

\subsubsection{Coincidental Conjunction}

Coincidental conjunction, which contrasts two different but related statements, is well-known to students of Slavic as it is here that a number of Slavic languages, 
including Slovene, demand a lexical distinction which is not obligatory in English. For example:

(21) Tvoj pes je bel, a moj je črn.

'Your dog is white and/while mine is black.'

In fact, this lexical distinction between coincidental conjunction and other types of conjunction is common to most Slavic languages. For example, in Bulgarian, Polish and Serbo-Croatian:

(22) Edni čakaxa pred garata, a drugi na perona.

'Some waited in front of the station and/?while/?but others on the platform.' (Atanassova et al. 1990: 13)

(23) On ptakat a oni się śmiali.

'He wept and/while/but they laughed.' (Stanisławski and Szercha 1993: 1)

(24) Ja sam veliki a moj brat je još mali.

'I'm big ?and/while/but my brother is still small.' (Magner 1972: 336)

Only a few of the Slavic languages have lost this distinction, using a more generally. For example, in Eastern Ruthenian, both coincidental and concomitant conjunction are expressed with $a$ :

(25) a. Korovy pasut' na toloci a vüvci pasut' na berezi.

'The cows are in the pasture and/while/but the sheep are up in the hills.' (Magocsi 1979: 58)

b. Sonce svityt' a nebo jasnoje.

'The sun is shining and/*while/*but the sky is clear.' (Magocsi 1979: 10)

\section{Ambiguity}

Dik (1968: 228-37) distinguished three types of ambiguity which are encountered in coordinate structures: functional, relational and hierarchical.

\subsection{Functional Ambiguity}

Functional ambiguity occurs in sentences of the type:

(26) My cats are black and white.

in which it is unknown whether the predicate is to be applied collectively or distributively to the subject; i.e., whether the cats are spotted or solid colored.

\subsection{Relational Ambiguity}

Relational ambiguity occurs in sentences of the type:

(27) Only old men and women are in the village.

in which the scope of the attribute is unknown; i.e., whether the subject is equal to old men and old women or women and old men.

\subsection{Hierarchical Ambiguity}

Hierarchical ambiguity occurs in sentences of the type:

(28) Tom and Dick and Harry lifted the stone. 
in which the stone may have been lifted once by three persons, three times by three different persons, or twice: once by one person, and once by two persons (there being two possibilities for this final grouping).

While the structure of a sentence like (28) may be completely ambiguous, oftentimes a hierarchical structure may be read into the sentence by nesting certain conjuncts. Dik (1968: 30) states that although Cjs conjoin elements "at the same level of structural hierarchy," nonetheless "it is not excluded that in a coordinate expression different coordinated members occupy different structural levels." Such is apparently the case in the following Old Persian sentence:

(29) Yanunā tayaiy uškahaya $\bar{a}$ utā tayaiy drayahaya $\bar{a}$ utā dahayāva Greeks who mainland.LOC and who sea.LOC and lands.LOC tay $\bar{a}$ para draya.

which beyond sea.

'The Ionians who are of the mainland and who (dwell) on the sea, and the countries which are beyond the sea'

In analyzing this sentence, Klein (1988: 392) says that "there appears to be a hierarchical structure in which the two groups are taken as a unit and then conjoined with the (other) countries. The structure of this passage is therefore (X $u t \bar{a} \mathrm{Y}) u t \bar{a} \mathrm{Z}$."

\subsubsection{Non-Lexical Disambiguation}

It is also important to note that these structures are frequently disambiguated (at least in speech) through the appropriate placement of rising intonation. Such intonation can cue the listener as to which $\mathrm{Cj}$ are main $\mathrm{Cjs}$, and which are subordinate (Gleitman 1965: 276-77).

Hudson (1988: 318) shows how background knowledge can sometimes help resolve ambiguity by offering the sentences:

(30) a. Fred and Bill and Mary play piano trios every Friday.

b. Fred and Bill and Mary played a solo and a duet, respectively.

Knowing that it takes three to play a trio, (30a) does have a default interpretation, although it is conceivable that they all play trios with other people.

\subsubsection{Lexical Disambiguation}

Some languages seem to be able to disambiguate these larger conjunctions through the use of overtly hierarchically ordered Cjs. Such a lexical distinction appears to have been possible in Old Persian, as in the following:

(31) Pārsam [c] $\bar{a}$ Mādam [c]ā utā aniyā dahayāova

Persia.and Media.and and other lands

'Persia and Media and the other provinces'

where Klein (1988: 402) says that the text "appears to denote a part of the Achaemenid Empire to which is contrasted all other provinces. This passage therefore seems to suggest that $-c \bar{a}$ may function as a lower level or tighter conjunction than $u t \bar{a}$ and be capable of signaling an internal constituency within a conjoined structure." 
That is, the structure:

(32)

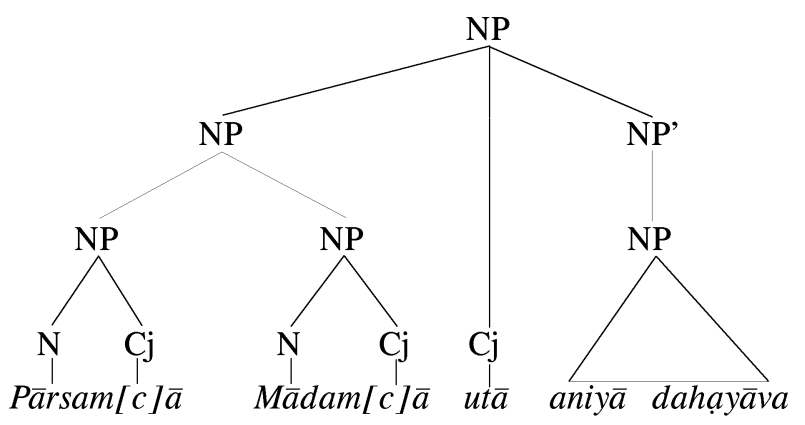

is suggested by the Cjs employed.

Such a distinction is also suggested for other ancient languages; e.g., Latin, Greek and Sanskrit. It has even been postulated that there was an original Indo-European hierarchical ordering of Cjs. In addressing this issue, Dunkel (1982: 181) concludes: "Were *kwe, *-Au and *-yo semantically or stylistically distinct? Probably, if only in the sense that some were 'newer' or more emphatic than others. The synchronic IE situation was roughly comparable to that in Latin (-que, et, atque),

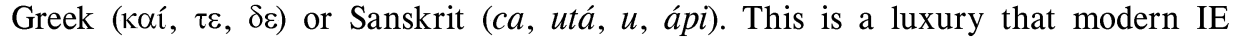
languages have by and large given up."

\subsubsection{Slavic}

However, a number of Slavic languages do nonetheless appear to preserve the ability to lexically differentiate higher- and lower-level constituency within conjoined structures.

In Polish, Grappin (1949: 288) notes that "dans le phrases où il sagit de plus de deux objets, $i$ et $a$ s'emploient côte à côte pour indiquer les groupes entre lesquels ces objets sont répartis." He gives the example:

(33) różnica między językiem szlacheckim a miejskim i gburskim

which he glosses as "la différence entre la langue des nobles, d'une part, et celle des bourgeois et manants, d'autre part." A similar example is seen in:

(34) Kanada a Anglia $i$ Stany Zjednoczone

which he glosses as "Canada devant l'Angleterre et les États-Unis."

The situation is even more striking in Slovene.

\subsubsection{Slovene}

Slovene is particularly rich in Cjs. As de Bray (1980: 369) observes, "These present no syntactical difficulties, but as Slovenian is far more fond of various modifying conjunctions and particles than English, they are often difficult to translate." Those Cjs generally translated as copulative 'and' are in, $p a$ and ter.

In is the most general of the Slovene copulative $\mathrm{Cj}$ s. This $\mathrm{Cj}$ can be used for ordered, identity and concomitant conjunction, while coincidental conjunction is usually expressed with $a$. Native speakers' perspective on $p a^{6}$ is usually that, while

${ }^{6} \mathrm{~Pa}$ may also be used as an enclitic particle, equivalent to Russian že, especially in questions (de Bray 1980: 369); e.g., Kaj pa delaš? 'What are you doing?'. 
synonymous with in and able to be used to express the same types of conjunction, it is more characteristic of colloquial speech and may be interpreted as having a supplementary feel; for example, in response to the question Koliko hlebov imate? 'How many loaves do you have?' we find the response:

(35) Sedem [hlebov], pa malo ribic.

'Seven [loaves], and a little fish (as well).' (Mt 15: 34)

Obviously, the choice between $p a$ and in is often determined at the discourse level, for now that both loaves and fish are thematically relevant, we see:

(36) ... vzel je sedmero hlebov in ribe...

'... he took the seven loaves and fish ...' (Mt 15: 36)

In contrast to $p a$, ter is usually felt to be restricted to literary language (and it is in literature that it is most often encountered), and it is even perceived as snobbish, although it is synonymous with in. ${ }^{7}$ It is frequently characterized as the $\mathrm{Cj}$ used for the last element in a list (Bajec et al. 1962: 889, Jurančič 1965: 272, Bajec et al. 1970: V. 64); for example:

(37) Vprašal nas je, kje smo dobili knjige in kaj smo brali ter kakšne zapiske smo si delali.

'He asked us where we had gotten the books and what we had read and what kinds of notes we made for ourselves.' (Jurančič 1965: 272)

Ter probably had greater range of use in the past, based on constructions like the following, from 1584:

(38) Auguftus inu Trajanue Sta bilá dobra tir modra v́juda.

'Augustus and Trajan were good and wise leaders.' (Bohorič 1584: II.55)

Despite their overt synonymy, these three Cjs may be used in combination with one another to disambiguate hierarchical ambiguity, such as that in (28), with the order ter-in-pa (structurally highest to lowest). For example,

(39) jaz pa Zora in ti pa Jana

'Zora and I and you and Jana'

necessitates the structure:

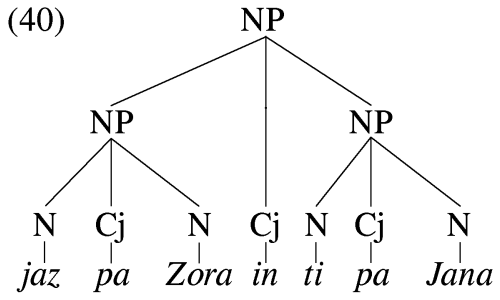

Ter is rarely used in locutions of this type, and constructions such as:

(41) ?Zora in ti ter Tomaž in jaz

'Zora and you and Tomaž and I'

\footnotetext{
${ }^{7}$ At least one source says that ter may not join nominal pairs (*oče ter mati 'father and mother') (Bajec 1962: 889); however, some informants find this construction awkward or stilted rather than ungrammatical.
} 
are deemed stilted, or even questionable. However, it is encountered more frequently with more complex conjuncts:

(42) ... je imela črne lase in črne oči ter bolno, rumeno polt.

'... [she] had black hair and black eyes and a sickly, yellow complexion.' (Cankar 1920: 8)

in which, presumably, the more similar features black hair and black eyes are conjoined at a lower level than the feature sickly, yellow complexion:

(43)

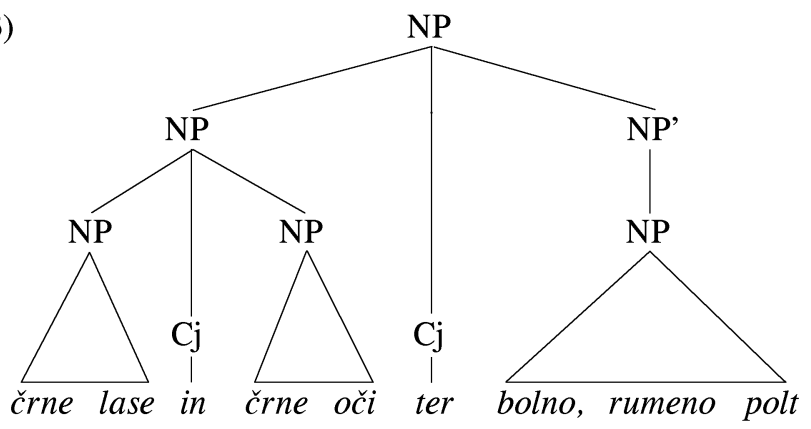

It is true that the use of ter in (42) is another example of it linking the last element in a list, as in (37), but it may not be possible to separate the roles of structural disambiguation vs. final element conjunction. It is natural that similar elements will be grouped together in a list; e.g.:

(44) a. He was walking with his son, daughter and dog.

b. ?He was walking with his son, dog and daughter.

or:

(45) a. The suspect has blue eyes, blond hair and a limp.

b. ?The suspect has blue eyes, a limp and blond hair.

So, although it is accurate to say that ter connects the last element in a list, the final-position use of ter may be determined by the structure, which sets off semantically disparate elements by default.

\subsubsection{Russian}

Russian seems to have no provision for disambiguating hierarchically ambiguous constructions through the use of different $\mathrm{Cj}$. The $\mathrm{Cj} d a$ is sometimes equated with Slovene ter (as in de Bray 1980: 369); but constructions like:

(46) Na večerinke byli Dmitrij i Nataša da Aleksandr $i$ Lena.

'Dmitri and Nataša and Aleksandr and Lena were at the party.'

sound hopelessly folkloric. However, usages like:

(47) Tam byli Petr, Aleksej da ja.

'Petr, Aleksej and I were there.'

at least echo the Slovene construction, though they are felt to be rather colloquial.

Constructions like (46) are either rephrased as: 
(48) Na večerinke byli Dmitrij, Nataša, Aleksandr i Lena.

'Dmitri, Nataša, Aleksandr and Lena were at the party.'

in which no hierarchical construction is expressed or inferred, or:

(49) Na večerinke byli Dmitrij s Natašej i Aleksandr s Lenoj.

'Dmitri and Nataša, and Aleksandr and Lena were at the party.'

in which the preposition $s$ 'with' functions as a lower-level conjunction and is used to produce the structure:

(50)

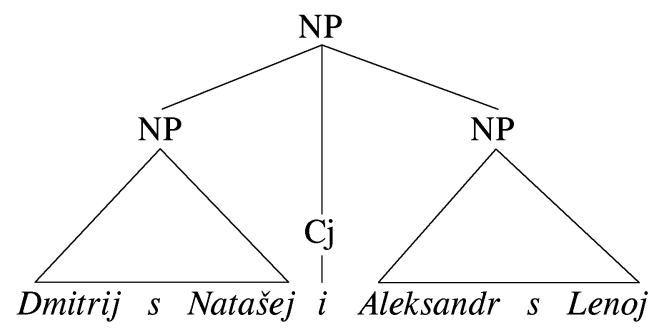

much as Slovene might with Cjs, as in (39).

\section{S-Coordination}

This comitative construction, which we might call $s$-coordination, is fundamentally different from cases in which $s$ functions to introduce a NP to complement the main NP. This can be illustrated by the following sentences:

(51) Dmitrij s Natašej *byl/byli na večerinke.

'Dmitri and Nataša were [*sg./pl.] at the party.'

(52) Ženščina s korobkoj poexala/*poexali na vokzal.

'A woman with a box went [*sg./pl.] to the train station.'

In the first, an example of $s$-coordination, Nataša is a co-participant in the event and her participant status is reflected in the number of the verb. In the second, the box is a mere accessory to the woman, and to assign it participant status would be most unusual.

$S$-coordination is also found in Slovene, ${ }^{8}$ where it may function identically to the Russian example in (49):

(53) Vinko z Marjano in Jože z Marico sta odšla.

'Vinko and Marjana, and Jože and Marica have left.'

Note that the perception of two groups is reflected in the verb, here a masculine dual.

$S$-coordination seems to be at a level below that of all other $\mathrm{Cjs},{ }^{9}$ potentially offering four levels of hierarchical distinction in Slovene coordinate structures, though encountering all of them in the same utterance would be unusual. The following example comes close:

\footnotetext{
${ }^{8}$ In Slovene the preposition is written $s$ only before voiceless consonants; otherwise it appears as $z$.

${ }^{9}$ Pit'ha (1986: 164) makes a similar observation with regard to Czech $a$ 'and' and $s$ 'with'.
} 
(54) hčerka Pavla $z$ družino, sin Andrej, sestri Marjana in Micka ter ostalo sorodstvo

'the daughter Pavla and her family, the son Andrej, the sisters Marjana and Micka and the remaining relatives' (Bajec et al. 1970: V. 64)

the structure of which can be represented as:



It is one of the unusual aspects of these $s$-coordinations that when they are used with pronouns the number of the pronouns is often increased by one (Slovene singular obligatorily becomes dual, while Russian 1st person singular obligatorily becomes plural):

(56) Midva s Petrom sva kupila hišo. we.DU with Peter bought.1-DU house 'Peter and I bought a house.'
(57) My s Petrom kupili dom. we with Peter bought.PL house 'Peter and I bought a house.'

This is probably to help motivate the logical verbal number, in view of the grammatically reduced participant status of the second conjunct. Nevertheless, the verbal number may be maintained without the pronoun in Slovene:

(58) nisva govorila $z \quad$ materjo nobene besede didn't speak.1-DU with mother no word 'Mother and I didn't speak a single word' (Cankar 1920: 63)

In order to compensate for its smaller stock of copulative Cjs, Russian allows a much more liberal use of $s$-coordination than Slovene. Table 1 shows the grammaticality of, and number of participants in, the various combinations of pronominal $s$-coordination in Slovene and Russian.

\begin{tabular}{lccccc} 
& Singular & Dual & Plural & Singular & Plural \\
1st p & $*$ & 2 & $*$ & $*$ & $2+$ \\
2nd p & $*$ & 2 & $*$ & 2 & $2+$ \\
3rd p & $*$ & $?$ & $*$ & 2 & $3+$ \\
& & Slovene & & \multicolumn{2}{c}{ Russian }
\end{tabular}

Table 1. Grammaticality and Participants in Slovene and Russian Pronominal $S$-Coordination 
Slovene also frequently seems to assign less participatory status to conjuncts linked by $s$ than does Russian. While Russians find the sentence:

(59) Ja ljublju pivo s vinom.

'I love beer and wine.'

unusual, as it restricts them to being drunk at the same sitting, Slovenes respond to:

(60) Rad imam pivo $z$ vinom.

'I like beer and wine.'

with disgust, as it implies that the two beverages are mixed.

Evidence for the lesser participatory status of $s$-coordinated conjuncts in Slovene is also seen in the pattern of verbal agreement. While Russian always finds the plural variants of the following sentences acceptable: ${ }^{10}$

(61) Ženščina s mužčinoj *byla/byli na ulice.

'A woman with/and a man *was/were on the street.'

(62) Ženščina s sobakoj byla/byli na ulice.

'A woman with/and a dog was/were on the street.'

Slovene always treats the non-pronominal $s$-coordinated NP as singular, and allows only the first conjunct to control verbal agreement:

(63) Žena z možem je bila/*sta bila na ulici.

'A woman with/and a man was/*were on the street.'

(64) Žena s psom je bila/*sta bila na ulici.

'A woman with/and a dog was/*were on the street.'

\section{Conclusions}

Of course, there are other ways of resolving the ambiguity of these constructions (e.g., through paraphrase) which destroy the coordinate structure, and native speakers are quick to suggest them, especially for the more awkward constructions. As a communicative act, language is able to tolerate much ambiguity. For example, the coordination of the gloss of (46) has at least 11 possible structures, yet we need not examine all of them to understand the statement.

Although hierarchical ambiguity can exist in coordinate structures, it has been shown that there can be higher and lower levels of coordination within these coordinate structures. Slavic languages are capable of resolving that ambiguity to a great degree through purely lexical means, albeit with different degrees of distinction and somewhat different mechanisms.

\footnotetext{
${ }^{10}$ The second variant of (62), though semntically odd, is grammatically acceptable.
} 


\section{References}

Atanassova et al. 1990. Bulgarian-English dictionary. Sofia: Nauka i izkustvo.

Bajec, Anton et al., eds. 1962. Slovenski pravopis. Ljubljana: SAZU.

Bajec, Anton et al., eds. 1970-91. Slovar slovenskega knjižnega jezika I-V. Ljubljana: Državna založba Slovenije.

Bohorič, Adam. 1584 (1970). Arcticae horulae. Ljubljana: Mladinska knjiga.

Borsley, Robert D. 1994. In defense of coordinate structures. Linguistic Analysis 24: $218-46$.

de Bray, R. G. A. 1980. Guide to the south Slavonic languages. Columbus: Slavica.

Dik, Simon C. 1968. Coordination: its implications for the theory of general linguistics. Amsterdam: North Holland.

Dunkel, George E. 1982. I.E. conjunctions: pleonism, ablaut, suppletion. Zeitschrift für vergleichende Sprachforschung 96: 178-99.

Gleitman, Lila R. 1965. Coordinating conjunctions in English. Language 41: 260-93.

Grappin, Henri. 1949. Grammaire de la langue polonaise. 2nd. ed. Paris: Institut des études Slaves.

Hudson, Richard. 1988. Coordination and grammatical relations. Journal of Linguistics 24: 303-42.

Jurančič, Janko. 1965. Slovenački jezik. Ljubljana: Državna založba Slovenije.

Klein, Jared S. 1988. Coordinate conjunction in Old Persian. Journal of the American Oriental Society 108: 387-417.

Lorentz, Friedrich. 1919 (1971). Kaschubische Grammatik. Hildesheim: Gerstenberg.

MacDonell, Arthur A. 1927 (1982). A Sanskrit grammar for students. Oxford: Oxford University Press.

Magner, Thomas F. 1972. Introduction to the Croatian and Serbian language. Ephrata: Science Press.

Oirsouw, Robert R. van. 1983. Coordinated sentences. Lingua 60: 135-45.

Oirsouw, Robert R. van. 1987. The syntax of coordination. London: Croom Helm.

Pit'ha, Petr. 1986. Four (simple) remarks on coordination. Language and discourse: test and protest. A festschrift for Petr Sgall. 163-69. Amsterdam: John Benjamins.

Rězak, Filip. 1920 (1987). Němsko-serbski wšowědny stownik hornjotužiskeje [serbskeje] rěče. Budyšin: Domovina.

Sag, Ivan A., Gerald Gazdar, Thomas Wasow and Steven Weisler. 1985. Coordination and how to distinguish categories. Natural Language and Linguistic Theory 3: $117-71$.

Slavutych, Yar. 1959. Conversational Ukrainian. Edmonton: Gateway.

Stanisławski, Jan, and Małgorzata Szercha. 1993. A practical Polish-English dictionary. Warsaw: Wiedza Powszechna.

Whitney, William Dwight. 1931. Sanskrit grammar. 2nd. ed. Cambridge: Harvard University Press. 


\section{Text Sources}

Cankar, Ivan. 1920 (1991). Moje življenje. Ljubljana: Tiskarna ljudske pravice.

Magocsi, Paul R. 1979. Let's speak Rusyn: Transcarpathian edition. Fairview: Carpatho-Rusyn Research Center.

Prispelo novembra 1996, sprejeto decembra 1996

Received November 1996, accepted December 1996

\section{Hierarhične dvoumnosti v vezalnih prirednih strukturah $v$ slovenščini in drugih slovanskih jezikih}

Lastnosti prirednosti so vroča tema v sodobni lingvistiki. Mnogi problemi, ki so še danes $\mathrm{v}$ ospredju jezikoslovnega raziskovanja, so pritegovali pozornost avtorjev že $\mathrm{v}$ času antike. Tako že Aristotel in Dionizij Traški razpravljata o derivaciji in članstvu v prirednih strukturah. $\mathrm{V}$ tem stoletju najdemo podobno razpravljanje $\mathrm{v}$ delih Bloomfielda in Chomskega.

Identificirati je mogoče nekaj vrst priredja. Vezalno priredje, ki izraža pomen 'in’ s priredjem (»dostavljanje« tipa $A B$ ), sestavljanjem (spojitev tipa $A B$ ) in vezanjem (besedno povezovanje $\mathrm{z}$ veznikom tipa $A$ in $B$ ), je glavna tema članka. Priredje in vezanje sta najpogostejša mehanizma prirednosti $v$ slovanskih jezikih. Po van Oirsouwu je vezanje mogoče deliti na zaporedno, identično, hkratno in naključno. Vse štiri vrste se uporabljajo $\mathrm{v}$ slovanskih jezikih $\mathrm{z}$ večjo ali manjšo stopnjo besedne različnosti.

Dvoumnost $\mathrm{v}$ teh vezalnih prirednih strukturah je funkcionalna, odnosna ali hierarhična. Nekateri avtorji so pokazali besedno »razdvoumljenje « teh dvoumnosti za klasične jezike, npr. staro perzijščino, latinščino, grščino in sanskrt. Čeprav se domneva, da današnji indoevropski jeziki takih struktur besedno ne "razdvoumljajo» več, nekateri slovanski jeziki vendarle lahko besedno razlikujejo članstvo na višji in nižji ravni v prirednih strukturah.

Slovenščina je v tem pogledu posebno bogata, saj ima tri vezalne veznike: ter, in, pa. Ti izražajo članstvo v prirednih strukturah od strukturno najvišjega do najnižjega, čeprav v njihovi rabi obstajajo stilistične omejitve. Drugi slovanski jeziki so v zmožnosti, da bi besedno »razdvoumili« priredne strukture, bolj omejeni.

Slovenščina in nekateri drugi slovanski jeziki imajo za izražanje prirednosti na še nižji ravni dodatni mehanizem s predlogom $z(s)$, npr. midva s Petrom. Vendar $\mathrm{v}$ različnih slovanskih jezikih opazimo variacije $\mathrm{v}$ slovničnosti in številu udeležencev $\mathrm{v}$ teh strukturah. Zlasti slovenščina je $\mathrm{v}$ rabi priredja s predlogom $z(s)$ bolj omejena kot ruščina. 


\section{Hierarchical Ambiguities in Copula Coordinate Structures in Slovene and Other Slavic Languages}

The nature of coordination is a current topic of debate in linguistic research. Many of the issues being discussed today, including derivation and constituency in coordinate structures, were debated by earlier writers, such as Aristotle and Dionysius Thrax, and have been paralleled in this century by linguists such as Bloomfield and Chomsky.

A number of coordination types are recognized. Copulative coordination, expressing 'and' is achieved through parataxis (juxtaposition of the type $A B$ ), composition (fusion of the type $A B$ ) and conjunction (lexical linkage of the type $A$ and $B)$, is the focus of this article. Parataxis and conjunction are the most frequently employed coordinate mechanisms in the Slavic languages. This latter can be subdivided, à la van Oirsouw, into ordered, identity, concomitant and coincidental conjunction. All four types occur in Slavic with varyingdegrees of lexical distinction.

Ambiguity in these copula coordinate structures is functional, relational or hierarchical. Lexical disambiguation of these ambiguities has been demonstrated or posited for classical languages such as Old Persian, Latin, Greek and Sanskrit. Although it has been assumed that the modern Indo-European languages no longer lexically disambiguate such constructions, some Slavic languages are able lexically to differentiate higher- and lower-level constituency within coordinate structures.

Slovene is particularly capable in this regard, employing three copulative conjunctions: ter, in and $p a$. These express structurally highest to lowest constituency in coordinatestructures, although there are stylistic limitations on their use. Other Slavic languages are more limited in their ability lexically to disambiguate coordinate structures.

A further coordination mechanism, expressed with the preposition $z(s)$ (e.g., midva s Petrom), can express yet a lower level of coordination in Slovene and some other Slavic languages. However, there is cross-linguistic variation in the grammaticality and number of participants of these constructions. In particular, Slovene is more limited than Russian in its use of coordination with the preposition $z(s)$. 